\title{
PENGARUH PEMBERIAN PAKAN ALAMI CACING Tubifex sp. TERHADAP PANJANG DAN BERAT IKAN RAMIREZI (Mikrogeophagus ramirezi)
}

\author{
Budianto $^{\mathrm{a}, *}$, Soko Nuswantoro ${ }^{\mathrm{a}}$, Heny Suprastyani ${ }^{\mathrm{a}}$, and Arning Wilujeng Ekawati ${ }^{\mathrm{a}}$ \\ ${ }^{a)}$ Program Studi Budidaya Perairan, Fakultas Perikanan dan Ilmu Kelautan \\ Universitas Brawijaya J1. Veteran Malang 65145, Indonesia \\ *Koresponden penulis: budianto.bp@ub.ac.id
}

\begin{abstract}
Abstrak
Salah satu ikan hias yang memiliki prospek perkembangan yang cukup baik adalah ikan ramirezi (Mikrogeophagus ramirezi). Dalam pemeliharaan ikan ramirezi diperlukan perlakuan khusus dalam penanganan benihnya. Tujuan dari penelitian ini yakni dapat mengetahui pengaruh pemberian pakan alami cacing Tubifex sp. terhadap pertambahan panjang dan berat benih ikan Ramirezi. Penelitian ini terdapat 2 perlakuan yakni perlakuan A (pemberian pakan pellet) dan perlakuan B (pemberian pakan cacing Tubifex sp). Pakan diberikan dua kali per hari pada waktu pagi dan sore. Masing-masing perlakuan dilakukan dengan 3 kali ulangan. Pakan pellet dan cacing Tubifex sp yang diberikan masing-masing secara ad libitum selama 14 hari. Hasil pengamatan dan perhitungan menunjukkan bahwa persentase pertambahan benih ikan pada perlakuan B mengalami peningkatan yang signifikan daripada hanya diberi pakan pellet saja (Perlakuan A). Selama 14 hari, pemberian pakan alami cacing Tubifex sp., benih ikan mengalami penambahan panjang sebesar $13,78 \%$ dan berat sebesar 106,48 \%. Hasil ini sangat jauh berbeda dengan benih ikan yang hanya diberi pakan pellet, yakni hanya $12,31 \%$ untuk beratnya dan tidak mengalami pertambahan panjang. Kesimpulan dari penelitian ini adalah pemberian pakan alami cacing Tubifex sp. berpengaruh signifikan terhadap pertambahan panjang dan berat benih ikan Ramirezi.
\end{abstract}

Kata Kunci : Berat, Cacing Tubifex sp, Ikan Ramirezi (Mikrogeophagus ramirezi), Panjang

\begin{abstract}
One of the ornamental fishes which has a fairly good development prospect is ramirezi fish (Mikrogeophagus ramirezi). In the maintenance of ramirezi fish is needed special treatment in handling the fish larvae. The purpose of this study was to determine the effect of natural feeding on the Tubifex sp. silkworm to increase the length and weight of ramirezi fish larvae. This study contained 2 treatments, namely treatment A (feeding pellets in the morning and evening) and treatment $B$ (feeding the Tubifex sp. silkworm in the morning and evening). Each treatment was carried out with 3 replications. Pellet feed and Tubifex sp. silkworm were given each ad libitum for 14 days. The results of this study showed that the percentage of fish seed increase in treatment $B$ experienced a significant increase rather than just given pellet feed (Treatment A). For 14 days, the natural feeding of the Tubifex sp. in the morning and evening, fish larvae experienced a length increase of $13.78 \%$ and weight of $106.48 \%$. This result is very different from fish larvae which were only given pellet feed in the morning and evening, which is only $12.31 \%$ for their weight and their length is fixed. The conclusion of this study is the natural feeding of Tubifex sp. have a significant effect on the length and weight of Ramirezi fish larvae.
\end{abstract}

Keywords: Length, Ramirezi Fish (Mikrogeophagus ramirezi), Silkworm (Tubifex sp.), Weight

\section{PENDAHULUAN}

Budidaya dan penjualan ikan hias pada sektor akuakultur dapat menyediakan kesempatan bagus bagi masyarakat, yakni kegiatan perikanan non-konsumsi yang dapat menyediakan lapangan pekerjaan dan income bagi masyarakat [1]. Salah satu ikan hias yang memiliki prospek perkembangan yang cukup baik adalah Ikan Ramirezi (Mikrogeophagus ramirezi). Ikan hias ini merupakan salah satu jenis ikan hias air tawar yang banyak diminati oleh para penggemar ikan hias di Indonesia. Salah satu daya tarik ikan Ramirezi yaitu bentuk dan warna tubuhnya yang sangat menarik. Ikan Ramirezi memiliki tubuh yang kecil dan dapat mencapai panjang maksimum $4-6 \mathrm{~cm}$. Variasi 
warna kuning, merah, hitam, dan biru yang dimiliki ikan ini menjadi daya tarik tersendiri bagi penghobi ikan hias. Menurut [2], ikan Ramirezi atau dikenal dengan Dwarf Cichlid berasal dari Amerika Selatan. Ikan ini memiliki variasi warna biru, hitam, dan merah, sehingga ikan ini banyak digunakan sebagai hewan peliharaan oleh para penghobi ikan hias air tawar.

Banyak para pembudidaya dan pengusaha ikan hias memelihara dan membudidayakan ikan hias tidak menggunakan perlakuan khusus dalam pemeliharaannya, sehingga dapat menyebabkan kematian massal pada ikan. Perhatian khusus seharusnya diberikan pada pemeliharaan larva dan benih ikan, karena pada fase ini merupakan fase kritis dalam fase siklus hidup ikan. Protein sebagai makanan merupakan sumber utama energi dan berperan penting dalam menentukan laju pertumbuhan ikan dalam setiap fase siklus hidupnya. Protein sebagai komponen dasar dalam jaringan tubuh hewan dan nutrien esensial untuk perawatan dan pertumbuhan ikan. Kebutuhan terhadap protein pada larva dan benih ikan lebih besar daripada induk ikan, demikian juga kebutuhan asam lemak esensial juga lebih besar [3]. Menurut [4], pemberian pakan alami yang sesuai dengan fase pertumbuhan ikan sangat penting dan dapat menentukan laju pertumbuhan, kelulusan hidup dan kanibalisme dari ikan Koi (Cyprinus carpio).

Salah satu pakan alami yang dapat digunakan sebagai pakan benih ikan adalah Cacing sutera (Tubifex sp.). Menurut [5], cacing Tubifex sp. ini merupakan pakan alami yang paling disukai oleh ikan air tawar. Cacing Tubifex sp. sangat baik bagi pertumbuhan ikan air tawar karena kandungan proteinnya tinggi. Kandungan gizi cacing Tubifex sp. yaitu 57\% protein, 13,30\% lemak, 2,04\% karbohidrat [6].

Salah satu masalah pada usaha budidaya ikan hias adalah pengadaan pakan yang baik sehingga perlu ada penanganan yang sungguhsungguh, mengingat pengadaan pakan yang tidak seimbang dengan kebutuhan ikan tersebut akan mengakibatkan pertumbuhan ikan tidak optimal. Salah satu cara untuk mengatasi masalah tersebut, yaitu dengan mempelajari kelulusan hidup dan pertumbuhan benih ikan Ramirezi yang diberikan pakan cacing Tubifex sp. yang dibandingkan dengan pemberian pakan pellet/buatan. Hal ini disebabkan pakan buatan mempunyai kekurangan antara lain kualitasnya akan menurun bila terlalu banyak tersisa dan terendam di dalam air. Sehingga tujuan dari penelitian ini yakni dapat mengetahui pengaruh pemberian pakan alami cacing Tubifex sp. terhadap pertambahan panjang dan berat benih ikan Ramirezi.

\section{BAHAN DAN METODE}

\section{Sampel Ikan}

Benih ikan Ramirezi diperoleh dari petani ikan hias di Desa Bangoan, Kecamatan Kedungwaru, Kabupaten Tulungagung, Jawa Timur. Benih yang digunakan berukuran panjang 3,19 $\pm 0,26 \mathrm{~cm}$ dengan berat $0,44 \pm 0,02$ gram. Menurut [2], sebelum diberikan perlakuan, benih ikan harus diadaptasikan terlebih dahulu. Pada penelitian ini benih ikan diadaptasikan dalam akuarium selama 4 hari.

Benih selama diadaptasikan diberi pakan pellet dengan pemberian pakan 2 kali sehari, dengan berat pakan $5 \%$ dari berat tubuhnya. Air akuarium dikondisikan dalam suhu $28^{\circ} \mathrm{C}$, DO 5 ppm, dan pH 7-8.

\section{Waktu dan Tempat Penelitian}

Penelitian ini dilaksanakan pada Bulan Agustus 2018, bertempat di UPT Budidaya Ikan Air Tawar Sumber pasir, Fakultas Perikanan dan Ilmu Kelautan, Malang.

\section{Desain Penelitian}

Pada penelitian ini menggunakan metode [7] dan [8] dengan sedikit modifikasi. Penelitian ini terdapat 2 perlakuan yakni perlakuan A (pemberian pakan pellet) dan perlakuan B (pemberian pakan cacing Tubifex sp.) masingmasing diberikan pada pagi dan sore hari. Masing-masing perlakuan dilakukan dengan 3 kali ulangan. Pakan pellet dan cacing Tubifex sp yang diberikan secara ad libitum. Metode ini didukung oleh [9] menggunakan pakan alami cacing Tubifex sp. untuk diberikan pada ikan Betutu (Oxyeleotris marmorata) secara ad libitum sebanyak 2 kali sehari pada pagi dan 
sore hari. Pakan pellet yang digunakan adalah pakan pellet benih PF-800 Prima Feed (Produk PT. Matahari Sakti) dengan kandungan protein 39 - 41\%, Lemak 5\%, Serat 6\%, Abu 16\%, dan Kadar Air $10 \%$.

Sebanyak 10 ekor benih ikan Ramirezi ditempatkan dalam setiap akuarium dengan ukuran $60 \times 40 \times 40 \mathrm{~cm}^{3}$. Panjang dan berat ikan diukur pada awal penebaran dan pada hari ke-14 hari dengan disertai penghitungan jumlah ikan yang mengalami kematian. Pergantian air dilakukan setiap hari dengan menggunakan metode sifon untuk mengurangi feses dan jumlah amonia dalam akuarium. Kualitas air seperti suhu, DO dan $\mathrm{pH}$ dilakukan pengukuran setiap hari untuk mengetahui perubahan kualitas air dalam akuarium.

\section{Perhitungan Kelulusan Hidup Ikan}

Perhitungan Kelulusan hidup ikan dihitung berdasarkan rumus yang digunakan [6], yakni:

$$
\mathrm{S}=\frac{\mathrm{Nt} \times 100 \%}{\mathrm{No}}
$$

Keterangan :

$\mathrm{S}=$ Derajat Kelangsungan Hidup (\%)

No $=$ Jumlah ikan yang ditebar pada awal penelitian (Ekor)

$\mathrm{Nt}=$ Jumlah ikan yang ditebar pada akhir penelitian (Ekor)

\section{Perhitungan Panjang dan Berat Ikan}

Laju pertumbuhan spesifik dan laju pertambahan panjang sebagai data pertumbuhan ikan diukur pada hari ke-7 untuk mengetahui pertambahan panjang dan berat ikan, sesuai yang dilakukan [10] dengan rumus:

a. Pertambahan Panjang Mutlak

$\mathrm{L}=(\mathrm{Lt}-\mathrm{Lo})$

Keterangan :

$\mathrm{L}=$ Pertambahan Panjang Mutlak (cm)

Lt $=$ Panjang Benih Akhir Pemeliharaan (cm)

Lo $=$ Panjang Benih Awal Pemeliharaan (cm)

b. Pertambahan Berat Mutlak

$\mathrm{W}=(\mathrm{Wt}-\mathrm{Wo})$

Keterangan :

$\mathrm{W}=$ Pertambahan Berat Mutlak (g)
Wt $=$ Berat Benih Akhir Pemeliharaan $(\mathrm{g})$

Wo $=$ Berat Benih Awal Pemeliharaan $(\mathrm{g})$

\section{Analisa Data}

Rancangan penelitian ini menggunakan uji-t student dua sampel bebas (tidak berpasangan) dengan menggunakan 2 variasi pemberian pakan dengan masing-masing 3 kali ulangan. Pengolahan data untuk pengujian statistik ini menggunakan perangkat lunak (software) Microsoft Excel 2013. Selang kepercayaan yang digunakan pada penelitian ini 0,05 .

\section{HASIL DAN PEMBAHASAN}

\section{Kelulusan Hidup Ikan}

Pada penelitian ini menunjukkan tingkat kelulusan hidup benih ramirezi yang dipelihara selama 14 hari menunjukkan tingkat perbedaan yang antara perlakuan A dan B. Kelulusan hidup benih ikan ramirezi pada perlakuan A lebih rendah daripada perlakuan $\mathrm{B}$, dengan nilai masing-masing sebesar $83,33 \pm 0,58 \%$ dan $96,67 \pm 0,58 \%$ (Gambar 1).

Hasil penelitian ini menunjukkan bahwa pemberian pakan alami cacing Tubifex sp. dapat meningkatkan kelulusan hidup benih ikan ramirezi. Hasil ini sesuai dengan penelitian Sarowar et. al., dalam [11], dimana benih ikan gabus (Channa sp.) yang diberi pakan hidup berupa cacing Tubifex sp. memiliki nilai kelangsungan hidup lebih baik dibandingkan benih ikan gabus yang diberi pakan buatan dan pakan ikan rucah. Namun selain itu, menurut [12] bahwa kelulusan hidup ikan sangat dipengaruhi oleh adaptasi terhadap makanan dan lingkungan, status kesehatan ikan, kepadatan ikan dan kualitas air yang mendukung bagi hidup ikan. 


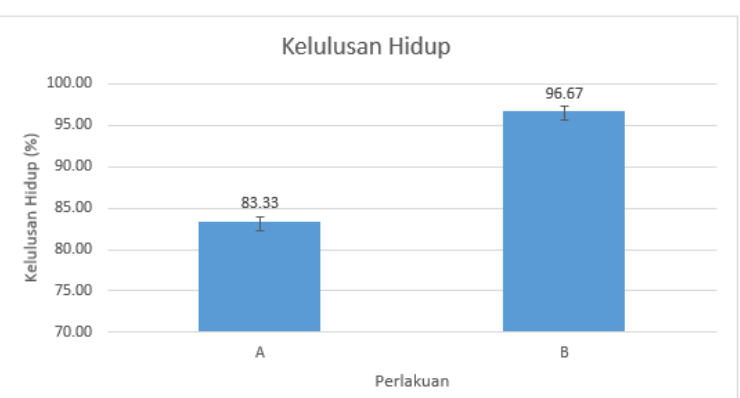

Gambar 1. Kelulusan Hidup Benih Ikan Ramirezi

\section{Panjang dan Berat Ikan}

Berdasarkan hasil pengukuran panjang benih ikan ramirezi (Tabel 1) dan hasil pengukuran berat benih ikan ramirezi menunjukkan benih ikan mengalami pertambahan panjang maupun beratnya (Tabel 2) selama pemeliharaan 14 hari.

Tabel 1. Hasil Pengukuran Panjang Benih Ikan Ramirezi

\begin{tabular}{ccccc}
\multirow{2}{*}{ Perlakuan } & \multicolumn{3}{c}{ Ulangan } & $\begin{array}{c}\text { Rerata } \\
\text { (cm) }\end{array}$ \\
\cline { 2 - 4 } & $\mathbf{1}$ & $\mathbf{2}$ & $\mathbf{3}$ & $3,19 \pm 0,00$ \\
$\mathrm{~A}$ & 3,19 & 3,19 & 3,19 & $3,19 \pm 0,20$ \\
$\mathrm{~B}$ & 3,78 & 3,72 & 3,42 & $3,64 \pm 0,20$ \\
\hline
\end{tabular}

Tabel 2. Hasil Pengukuran Berat Benih Ikan Ramirezi

\begin{tabular}{ccccc}
\hline \multirow{2}{*}{ Perlakuan } & \multicolumn{3}{c}{ Ulangan } & $\begin{array}{c}\text { Rerata } \\
\text { (gr) }\end{array}$ \\
\cline { 2 - 4 } & $\mathbf{1}$ & $\mathbf{2}$ & $\mathbf{3}$ & $0,49 \pm 0,07$ \\
$\mathrm{~A}$ & 0,58 & 0,46 & 0,45 & $0,490,12$ \\
$\mathrm{~B}$ & 0,91 & 0,80 & 1,03 & $0,91 \pm 0,12$ \\
\hline
\end{tabular}

Hasil pengamatan dan perhitungan pada Tabel 3 dan 4 di atas terlihat bahwa persentase pertambahan benih ikan yang diberi pakan alami cacing Tubifex sp. (Perlakuan B) mengalami peningkatan yang signifikan dari pada hanya diberi pakan pellet saja (Perlakuan A). Hasil penelitian menunjukkan perbedaan yang signifikan terlihat dalam grafik pada Gambar 2 dan 3.

Selama 14 hari pemberian pakan alami cacing Tubifex sp. pada waktu pagi dan sore, benih ikan mengalami penambahan panjang sebesar 13,78 \% dan berat sebesar 106,48\%. Hasil ini sangat jauh berbeda dengan benih ikan yang hanya diberi pakan pellet pada pagi dan sore hari, yakni hanya $12,31 \%$ untuk beratnya dan panjangnya tetap.

Berdasarkan perhitungan uji $\mathrm{T}$, terdapat perbedaan secara nyata antara pemberian pakan alami cacing Tubifex sp. dengan pakan pellet terhadap pertambahan panjang benih ikan ramirezi dengan nilai probabilitas sebesar 0,03 atau nilai probabilitas sig $<0,05$. Sedangkan dari data pengukuran berat benih ikan ramirezi, data menunjukkan bahwa juga terdapat perbedaan secara nyata antara pemberian pakan alami cacing Tubifex sp. dengan pakan pellet dengan nilai probabilitas sebesar 0,007 atau nilai probabilitas sig $<0,05$.

Tabel 3. Pertambahan Panjang Mutlak Benih Ikan Ramirezi

\begin{tabular}{ccccc}
\hline $\begin{array}{c}\text { Perlaku- } \\
\text { an }\end{array}$ & $\begin{array}{c}\text { Lo } \\
(\mathbf{c m})\end{array}$ & $\begin{array}{c}\text { Lt } \\
(\mathbf{c m})\end{array}$ & $\begin{array}{c}\text { Pertambah- } \\
\text { an Panjang } \\
(\mathbf{c m})\end{array}$ & $\begin{array}{c}\text { Persen- } \\
\text { tase }(\mathbf{\%})\end{array}$ \\
\hline A & 3,19 & 3,19 & 0,00 & 0,00 \\
B & 3,19 & 3,64 & 0,45 & 14,14 \\
\hline
\end{tabular}

Tabel 4. Pertambahan Berat Mutlak Benih Ikan Ramirezi

\begin{tabular}{ccccc}
$\begin{array}{c}\text { Perlaku- } \\
\text { an }\end{array}$ & $\begin{array}{c}\text { Wo } \\
(\mathbf{g r})\end{array}$ & $\begin{array}{c}\text { Wt } \\
(\mathbf{g r})\end{array}$ & $\begin{array}{c}\text { Pertambah- } \\
\text { an berat }(\mathbf{g r})\end{array}$ & $\begin{array}{c}\text { Persen- } \\
\text { tase }(\boldsymbol{\%})\end{array}$ \\
\hline A & 0,44 & 0,49 & 0,05 & 12,31 \\
B & 0,44 & 0,91 & 0,47 & 106,48 \\
\hline
\end{tabular}

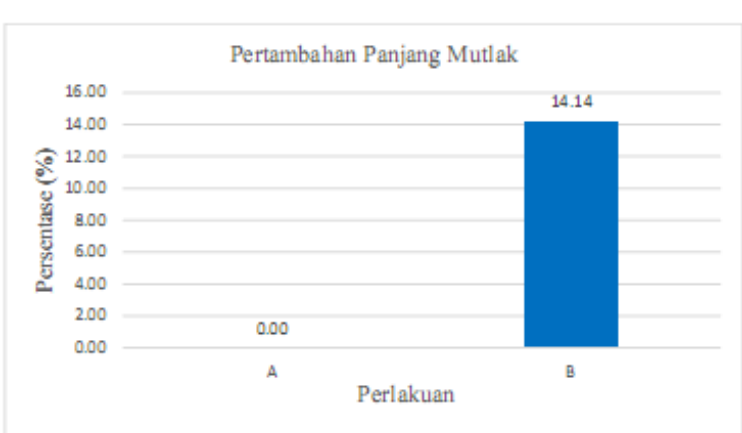

Gambar 2. Persentase Pertambahan Panjang Mutlak Benih Ikan Ramirezi

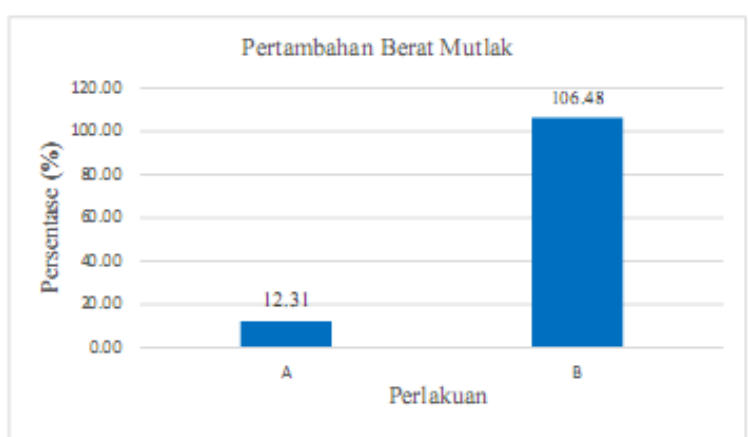

Gambar 3. Persentase Pertambahan Berat Mutlak Benih Ikan Ramirezi

Pertumbuhan suatu ikan ditunjukkan dengan perubahan (bertambahnya) panjang maupun berat tubuhnya [9]. Lebih lanjut lagi, 
pertumbuhan ikan erat kaitannya dengan ketersediaan protein dalam pakan, karena protein merupakan sumber energi bagi ikan dan protein merupakan nutrisi yang sangat dibutuhkan ikan untuk pertumbuhan. Pada hasil pengamatan menunjukkan pemberian pakan alami cacing Tubifex sp. memiliki hasil terbaik dibandingkan dengan pemberian pellet. Hasil ini sesuai dengan hasil penelitian [9] yang menggunakan pakan alami cacing Tubifex sp., cacing darah (larva Chironomus sp.), ikan mas (Cyprinus carpio), dan pellet pada Ikan Betutu (Oxyeleotris marmorata). Hasil penelitiannya menunjukkan pemberian pakan alami cacing Tubifex sp. memberikan pakan lebih baik dari pada pakan pellet.

Cacing Tubifex sp. merupakan pakan alami yang paling disukai oleh ikan air tawar. Cacing Tubifex sp. sangat baik bagi pertumbuhan ikan air tawar karena kandungan proteinnya tinggi [5]. Kandungan gizi cacing Tubifex sp. yaitu $57 \%$ protein, $13,30 \%$ lemak, $2,04 \%$ karbohidrat [6]. Selain itu menurut [12], pertumbuhan pada ikan tidak hanya dipengaruhi oleh kuantitas dan kualitas pakan, tetapi juga dipengaruhi oleh frekuensi dan kemampuan ikan dalam memanfaatkan pakan untuk kelangsungan hidup, metabolisme, pergerakan dan pertumbuhan. Kualitas air juga mempengaruhi kelangsungan hidup dan pertumbuhan ikan, kualitas air yang optimal akan meningkatkan nafsu makan ikan sehingga pertumbuhan akan meningkat.

\section{KESIMPULAN}

Kesimpulan dari penelitian ini adalah pemberian pakan alami cacing Tubifex sp. berpengaruh signifikan terhadap pertambahan panjang dan berat benih ikan Ramirezi. Pada pemberian pakan alami cacing Tubifex sp. pada benih ikan mengalami penambahan panjang sebesar 13,78 \% dan berat sebesar 106,48\%. Hasil ini sangat jauh berbeda dengan benih ikan yang hanya diberi pakan pellet pada pagi dan sore hari, yakni hanya $12,31 \%$ untuk beratnya dan panjangnya tetap.

\section{DAFTAR PUSTAKA}

[1] Abraham, T.J., A. Dasgupta, and T. Banerjee. "Effect of feeding bioencapsulated Lactobacillus sp. in live Tubifex sp. on the growth performance of gold fish Carassius auratus Linnaeus, 1758”. Bangladesh J. Fish. Res., 14(1-2): 1-8. 2010.

[2] Harpaz, S., and D. Padowicz. "Color Enhancement in the Ornamental Dwarf Cichlid Microgeophagus ramirezi by Addition of Plant Carotenoids to the Fish Diet". The Israeli Journal of Aquaculture Bamidgeh, 59(4); 195-200. 2007.

[3] Mahfuj, M.S., M.A. Hossain, and M.G. Sarower. "Effect of different feeds on larval development and survival of ornamental koi carp, Cyprinus carpio (Linnaeus, 1758) larvae in laboratory condition". J. Bangladesh Agril. Univ. 10(1): 179-183. 2012.

[4] Janakiraman, A. and Altaff, K. "Koi carp (Cyprinus carpio) larval rearing with different zooplankton live feeds to evaluate their suitability and growth performance". International J. Res. Fisher. Aquacult. , 4(4): 181-185, 2014.

[5] Subandiyah, S., Satyani, D., dan Aliyah. "Pengaruh substitusi pakan alami (tubifex) Dan buatan Terhadap pertumbuhan Ikan Tilan Lurik Merah (Mastacembelus erythrotaenia Bleeker, 1850)". Jurnal Iktiologi Indonesia, 3(2): 67-72, 2003.

[6] Madinawati, N. Serdiati, dan Yoel. "Pemberian Pakan yang Berbeda terhadap Pertumbuhan dan Kelangsungan Hidup Benih Ikan Lele Dumbo (Clarias gariepinus)". Media Litbang Sulteng 4(2): $83-87,2011$.

[7] Nuswantoro, S., and S.S.P. Rahardjo. "Effect of Using Silkworm (Tubifex Sp.) Living on The Survival Rate And Growth of The Catfish Larvae (Clarias Sp.)". IOSR 
Journal of Agriculture and Veterinary Science (IOSR-JAVS), 1(2); 42-46, 2018.

[8] Arain, K., N.T. Narejo, S. Jalbani, and P. Khan. "Effect of Different Feeds on Growth and Survival of Tilapia nilotica Reared in Cemented Cisterns". Sindh Univ. Res. Jour. (Sci. Ser.), 47(4); 643-644, 2015.

[9] Aggraeni, N.M., dan N. Abdulgani. "Pengaruh Pemberian Pakan Alami dan Pakan Buatan Terhadap Pertumbuhan Ikan Betutu (Oxyeleotris marmorata) pada Skala Laboratorium". Jurnal Sains Dan Seni Pomits, 2(1): 2337-3520, 2013.

[10] Saputra, H., A. Nikhlani., dan Isriansyah. "Kombinasi Pakan Alami Cacing Tubifex sp. dan Pakan Buatan Terhadap Kelangsungan Hidup Dan Pertumbuhan Benih Ikan Gabus (Channa striata Bloch) Dalam Upaya Domestikasi Ikan Spesifik Lokal". J. Aquawarman. 2 (2) : 20-27, 2016.

[11] Sasanti, A. D., dan Yulisman. "Pertumbuhan dan Kelangsungan Hidup Benih Ikan Gabus (Channa striata) yang Diberi Pakan Buatan Berbahan Baku Tepung Keong Mas (Pomacea sp.)". Jurnal Lahan Suboptimal. 1(2): 158-162, 2012.

[12] Mulyani, Y. S. "Pertumbuhan dan Efisiensi Pakan Ikan Nila (Oreochromis niloticus) yang Dipuasakan Secara Periodik”. Jurnal Akuakultur Rawa Indonesia. Fakultas Pertanian UNSRI. 2(1). 01-12, 2014.

[13] Mudjiman, 1984. "Makanan Ikan. PT. Penebar Swadaya". Jakarta 